\title{
Quantification, analysis and modelling of soil erosion on steep slopes using LiDAR and UAV photographs
}

\author{
F. NEUGIRG ${ }^{1}$, A. KAISER ${ }^{2}$, J. SCHMIDT ${ }^{2}$, M. BECHT ${ }^{1}$ \& F. HAAS ${ }^{1}$ \\ 1 Department of Physical Geography, Catholic University of Eichstätt-Ingolstadt, D-85072 Eichstätt, Germany \\ f.neugirg@ku.de \\ 2 Soil and Water Conservation Unit, Technical University Bergakademie Freiberg, D-09599 Freiberg, Germany
}

\begin{abstract}
Steep hill slopes in the Bavarian Alps and at an artificial waste dump on the Island of Elba are subject to soil erosion through geomorphological processes. Long-term high-resolution terrestrial LiDAR data are available and have been analysed for both areas. The analysis indicated different erosion patterns on the slopes that could be the result of different geomorphological processes. Additionally, both study sites show a good agreement between the annual erosion rates and the size of the hydrological catchment as a proxy for the sediment contributing area. The results presented in this study represent the first analysis of hill slope erosion measured with LiDAR and UAV systems. The hill slope erosion will be subject to measurements using a higher temporal resolution during future years in order to identify different erosion processes throughout the annual time step.
\end{abstract}

Key words terrestrial LiDAR; hill slope erosion; modelling; sediment contributing area; Bavarian Alps; Italy; UAV; photogrammetry

\section{INTRODUCTION}

Due to its process intensity, fluvial erosion plays a major role in the geomorphic system (Bryan 2000). Badland gullies, especially steep and barely vegetated slopes with unconsolidated material, are especially prone to fluvial erosion. But, the erosion and thus the sediment delivery from such slopes are not only driven by fluvial erosion alone. Other geomorphic processes (e.g. debris flows, slope failure), whose occurrence is dependent on the climate and topographic conditions, as well as on the composition of the material, can be key drivers of erosion on risky slopes.

Up to now, various studies have investigated slope erosion on steep slopes. Most of these used classic measurement methods, e.g. erosion pins or sediment traps (cf. Becht 1995; Sirvent et al., 1997; Evans \& Warburton 2005; Clarke \& Rendell 2006; Haas \& Heckmann 2007; Haas 2008; Della Seta et al., 2009). These methods are error-prone as the natural processes on the target slopes are potentially influenced by the installed traps or pins. Additionally, these techniques are hard to deploy on very steep slopes. The biggest disadvantage of these methods is, however, that the slopes can only be monitored with limited spatial and temporal resolution. This hampers interpretation and the transferability of the results, particularly with regard to the understanding of the interactions of the key processes (Haas, 2008).

During the last couple of years, terrestrial laser scanning (TLS), also referred to as LiDAR (Light Detection And Ranging) has become a widely accepted tool in geomorphological research (Milan et al., 2007; Schürch et al., 2011; Haas et al., 2011). LiDAR allows the remote sensing of steep slopes from close distances with a very high spatial (and temporal) resolution and without compromising the measured areas. Many studies show that, using this method, geomorphic processes can be quantified and analysed in detail (e.g. Milan et al., 2007; Haas et al., 2012a, 2012b).

The use of TLS can, however, also be very challenging, especially in high complexity landscapes. In badland gullies, for instance, with their ridges and deep channels, shadowing effects can lead to gaps in the measured point cloud. This effect can be minimized - even if it is very time consuming - by scanning the gullies from more than one scan position and matching them together (which can be a potential error source). The resulting point cloud normally has less data gaps but the point density is very inhomogeneous and thus the processing of the raw data and the derivation of digital elevation models (DEMs) can be very difficult and not without errors. This is why some recent studies use and improve the structure from motion method (SfM), the use of which has 
increased drastically over the last few years. On this basis, it is probable that the generation of DEMs from aerial photographs acquired with unmanned aerial vehicles (UAV) will become an important tool in soil erosion investigations (d'Oleire-Oltmanns et al., 2012; Wirtz et al., 2012; Peter et al., 2014). As the slopes can be observed from above using UAVs, shadowing effects do not normally occur and the generated point clouds have very homogenous and high point densities, which improves DEM generation.

In the context of the above, the study reported here has two key aspects. The first, is the quantification and analysis of erosion on steep slopes in very different climatic settings by using long time series of TLS data. The second aspect of this paper provides a brief outlook into how UAV-derived data can improve the measurement of erosion in complex topography.

\section{STUDY AREAS}

\section{The Lainbach valley catchment, Germany}

The Lainbach valley catchment is located $70 \mathrm{~km}$ south of Munich near Benediktbeuern in Upper Bavaria, at the marginal Northern Limestone Alps (Fig. 1). According to Felix (1988), the mean precipitation is approx. $2180 \mathrm{~mm}$ with about one third of the annual precipitation as snow and a mean annual temperature of $5.9^{\circ} \mathrm{C}$ (Priesmeier, 1988). The whole catchment spans an area of $>18 \mathrm{~km}^{2}$, with altitudes of 675-1800 m a.s.l. Mixed forests of natural vegetation, which mainly consists of spruce, fir and beech, can be found all over the catchment up to $1500 \mathrm{~m}$. Quaternary unconsolidated glacial fills from several glacial advances of the Loisach Glacier are present up to elevations of $1020 \mathrm{~m}$ (Becht, 1995). These glacial tills, with depths of up to $150 \mathrm{~m}$, are extremely unstable, which is visible through the presence of several erosion scars. These scars are the result of slips and slope failures and are prone to fluvial erosion and other geomorphic processes.

\section{Rio Marina, Island of Elba, Italy}

The second study site is located between Rio Marina and Cavo on the eastern coast of the Island of Elba in the Tyrrhenian Sea, close to the west coast of Italy (Fig. 1). The climatic conditions are characterised by precipitation during winter, with a mean annual rainfall of approx. $750 \mathrm{~mm}$ and a mean annual temperature of $15.3^{\circ} \mathrm{C}$ (for Populonia, located on the Italian mainland close to Elba). The region is normally without snow cover, especially in the areas close to the sea.

The monitored slope represents a waste dump of the former iron ore (haematite and pyrite) mine, Rio Albano. Mining ceased in 1981, but the waste dumps are still a potential source of heavy metal pollutants. Work by Servida et al. (2009) reported very high heavy metal

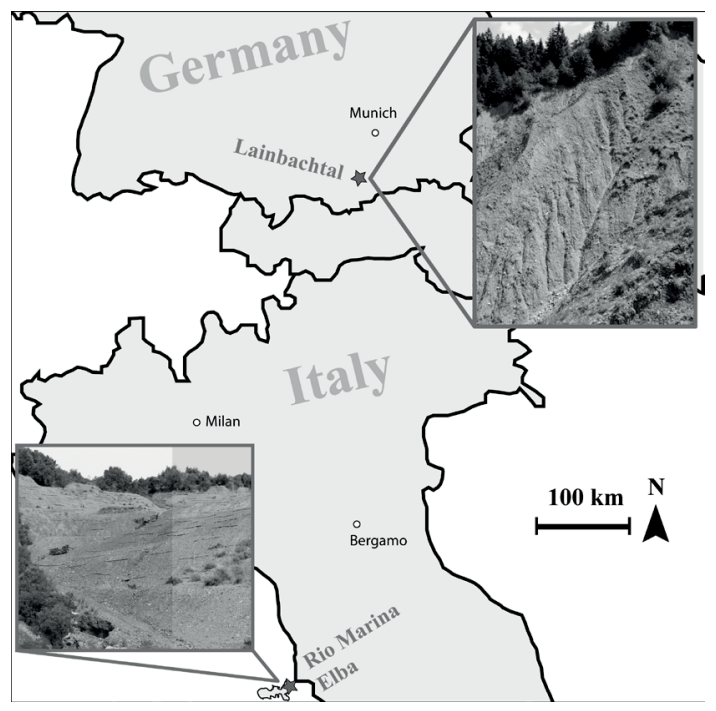

Fig. 1 Location of the two study areas in the Lainbach valley (Bavaria, Gemany) and at the former iron ore mine near Rio Marina on the island of Elba (Tuscany, Italy) in the Tyrrhenian Sea. 
concentrations (e.g. $903 \mathrm{mg} / \mathrm{L} \mathrm{Fe}$ ) and $\mathrm{pH}$ values of 2.1 to 3.4, which demonstrate the acid soil and water conditions of these slopes. The deposited waste consists mainly of coarse ( $>$ sand) mine filling material and slag, and is strongly affected by erosion processes. Due to the very acid conditions, which preclude erosion control by vegetation, the slopes have to be stabilized by artificial objects (Fig. 1). Slope gradients along the entire $650 \mathrm{~m}^{2}$ slope, which has a southern aspect, are in the range $14^{\circ}$ to $69^{\circ}$, with a mean value of $39^{\circ}$.

The whole waste dump is divided in four smaller slopes with artificial terraces. The accumulated overland flow that reaches the terraces is directed in small channels and flows to a constructed channel at the southern part of the study site. At the end of this artificial channel, the water has to pass a flat plain at the foot of the slope where most of the eroded material is deposited.

\section{METHODS}

\section{Terrestrial Laser Scanning (TLS) system}

For this study, we used a LMS Z420i from Riegl Laser measurement systems. This long-range 3D laser scanner is based on the time-of-flight principle. It operates with wavelengths in the near infrared and has a maximum measurement range of $1000 \mathrm{~m}$. Using rotating mirrors for receiving returning laser pulses, this model can sample a maximum of 8000 points per second. The scanner is additionally equipped with a mounted digital SLR camera (Canon EOS 350D, Nikon D70) for acquiring high resolution images of the scanned object, in order to colorize the point clouds. Table 1 summarises the TLS data.

Table 1 Properties of the TLS data

\begin{tabular}{lllll}
\hline & Data acquisition & Scan positions & $\begin{array}{l}\text { Number of } \\
\text { points (raw) }\end{array}$ & Point density at the slope \\
\hline Lainbach valley & July 2009 & 1 & 3705425 & 811 points $/ \mathrm{m}^{2}$ \\
& October 2013 & 3 & 10246400 & 2264 points $/ \mathrm{m}^{2}$ \\
Rio Marina & September 2009 & 7 & 44277575 & 3536 points $/ \mathrm{m}^{2}$ \\
& April 2012 & 11 & 46542218 & 3717 points $/ \mathrm{m}^{2}$ \\
\hline
\end{tabular}

\section{Workflow for TLS}

As the width of the laser beam increases with the range between TLS and the scanned object, it is favourable to be as close as possible to the scanned slopes during data acquisition. Ridges, vegetation or big boulders on the hill slope lead to shadowing effects in the point clouds. To minimize these data gaps, the slopes were scanned from several positions. To ensure high accurate co-registration of the different scan positions, we used an ICP (iterative closest point) algorithm. To co-register point clouds from different time steps, retro-reflective tie points were used. All steps of the data acquisition were undertaken using the software RiScan Pro that comes with the TLS system.

For further post-processing, the point clouds are ASCII formatted and exported from RiScan Pro to import them into a database of LIS Desktop/SAGA GIS (Rieg et al., 2014), where all filtering steps and analyses can be performed. Green vegetation filtering is performed using RGB colour values from the acquired images (Haas et al., 2011). For filtering non-green vegetation (e.g. branches) the point clouds are segmented in planes to distinguish between "true" ground points and vegetational points. Filtered point clouds were gridded with cell sizes of 0.1 (Lainbach) and 0.2 (Elba) $\mathrm{m}$. The detailed workflow of the processing of the raw data in RiscanPro and the following steps in LIS Desktop/SAGA GIS are described in detail by Haas et al. (2011, 2012b).

\section{Photogrammetry using an UAV}

During the field campaign in April 2013, the Rio Marina mining area was monitored using an UAV (Falcon 8 Octocopter by Astec Ascending technologies) with a mounted Sony camera Nex 5 
(resolution 14 Megapixel). The system comes with a remote control and an auto pilot system (altimeter, GPS, inclination sensors, gravity sensor) and can be operated automatically using an external PC and a flight plan. Due to the very complex topography of the study slope, the UAV was operated manually by the pilot (mean flight height: $50 \mathrm{~m}$ ). During the flights, 48 pictures with an overlap of at least $60 \%$ were taken. For the production of orthophotos and 3D point clouds of the study area, an exterior orientation was required (Lindner, 2006). Thus, a sum of 22 "true ground points" (red crosses that were distributed over the slope) were measured in the field by using a differential GPS with a GNSS antenna (Leica GS09). The ortho-rectified images and point clouds were subsequently derived using the software PHOTOSCAN PROFESSIONAL (Agisoft). The resulting point clouds were ASCII formatted and exported in order to use LIS Desktop/SAGA GIS for subsequent analysis.

\section{Statistical analysis - catchment size and sediment delivery}

Haas et al. (2011) showed a statistical correlation between sediment delivery (measured by sediment traps) and the size of the sediment contributing area (SCA), which is derived by a rulebased approach taking into account topographic values (slope and distance to the channel network) as well as vegetation cover. To quantify annual sediment delivery without installing sediment traps, "virtual traps" (several raster cells) were identified at the lowest parts of channels and gullies on the investigated slopes. The significant elevation changes from multi-temporal LiDAR data were routed downslope to these "virtual traps" using the module "Catchment Area (Parallel)" in SAGA GIS. The absence of vegetation, the location at the most upper part of the hill slope and the sufficiently high slope angles of the investigated slopes, allowed use of the hydrological catchment as proxy data for the SCA for each "virtual trap". The hydrological catchment size of every "virtual trap" was derived using the module "Catchment Area (Parallel)". To eliminate the flat slope terraces at the Rio Marina study site, the steep slope areas were clipped and each slope segment was isolated and equipped with several "virtual traps".

\section{RESULTS AND DISCUSSION}

\section{Quantification of slope erosion in the Lainbach valley catchment, Germany}

During the four year survey period between July 2009 and October 2013 (Table 2), a total of $34.0 \mathrm{~m}^{3}$ of material were eroded of which $6.1 \mathrm{~m}^{3}$ was deposited on other parts of the $265 \mathrm{~m}^{2}$ hill slope. Scaling up, a total of $27.9 \mathrm{~m}^{3}$ of mobilised sediment reached the channel network. The entire slope was lowered by $14.7 \mathrm{~cm}$ on average during the four-year study period. The annual lowering rates of $3.4 \mathrm{~cm}$ year $^{-1}$ lie in the range of values reported by other study areas with glaciogenic deposits in the Northern and Central Alps. For example, Haas (2008) reported $2.5 \mathrm{~cm}^{\text {year }}{ }^{-1}$ in the Lahnenwiesgraben (Bavarian Alps) and Becht (1995) $4.3 \mathrm{~cm}^{\text {year }}{ }^{-1}$ in the Horlachtal (Oetztal Alps). The highest erosion rates $(>0.5 \mathrm{~m})$ were measured at the foot of the gully slopes reflecting lateral fluvial erosion. In addition, areas with extensive erosion generated by non-fluvial processes were identified at the top and bottom of the study slopes (Fig. 2). Gullying occurred mainly on the lower part of the slope. The most extensive erosion areas might be the result of translational slides in connection with snow melt. This assumption corresponds with the conclusions of Becht \& Wetzel (1992).

\section{Quantification of slope erosion at the Rio Marina mine, Elba, Italy}

Erosion mainly occurred in conjunction with the heads of rills and artificial drainage channels. However, some parts of the slope were also subject to more extensive erosion, suggesting slope wash and small-scale slides. Break lines in the upper parts of the slopes suggested small-scale slope failures. Accumulation was focused on two parts in the flat area at the lowest points of the study slope (Fig. 3). In total (Table 3), $230.9 \mathrm{~m}^{3}$ of sediment was eroded during the three year period between 2009 and 2012. Within the study area, $73.2 \mathrm{~m}^{3}$ of sediment was redeposited. Due to the slope terraces and the flat plain in the lowest part of the mine, about $33 \%$ of the total eroded 
Table 2 Summary characteristics and sediment budgets for the study areas.

\begin{tabular}{lll}
\hline & Lainbach valley & Rio Marina \\
\hline Climatic conditions & $\begin{array}{l}\text { 1/3 of annual precipitation as snow, } \\
\text { temporal snow cover }\end{array}$ & No snow cover \\
Potential geomorphological & $\begin{array}{l}\text { Rill erosion, debris flows, freeze and } \\
\text { thaw processes, slope failures/slides }\end{array}$ & $\begin{array}{l}\text { Rill erosion, sheet wash, debris } \\
\text { flows, minor slope failures/slides }\end{array}$ \\
Soil properties & Glacial till & Coarse mine filling $(>$ sand) \\
Mean annual erosion & $3.4 \mathrm{~cm}$ year -1 & $1.5 \mathrm{~cm} \mathrm{year}^{-1}$ \\
Mean slope angle & $51^{\circ}$ & $26^{\circ}$ \\
Erosion (entire study period) & $34.00 \mathrm{~m}^{3}$ & $230.9 \mathrm{~m}^{3}$ \\
Deposition (entire study period) & $6.1 \mathrm{~m}^{3}$ & $73.2 \mathrm{~m}^{3}$ \\
Net export from the study area & $27.9 \mathrm{~m}^{3}$ & $175.8 \mathrm{~m}^{3}$ \\
\hline
\end{tabular}

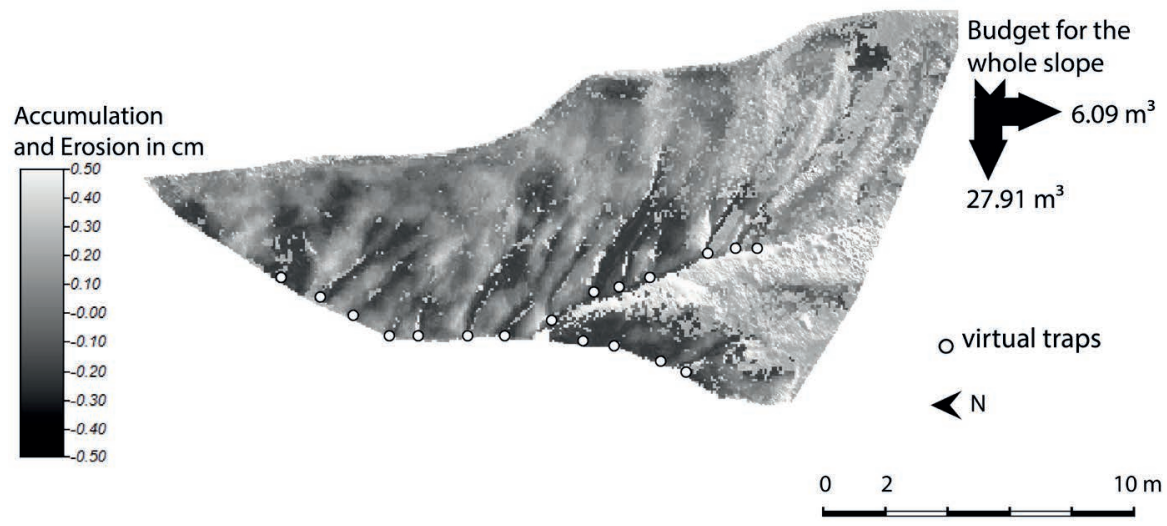

Fig. 2 Erosion and accumulation estimates for the hill slope in the Lainbach valley from July 2009 to Oct. 2013. The arrows indicate the amount of material deposited on the slope and transported out of the study area. "Virtual traps" at the bottom of the gullies are represented by circles.
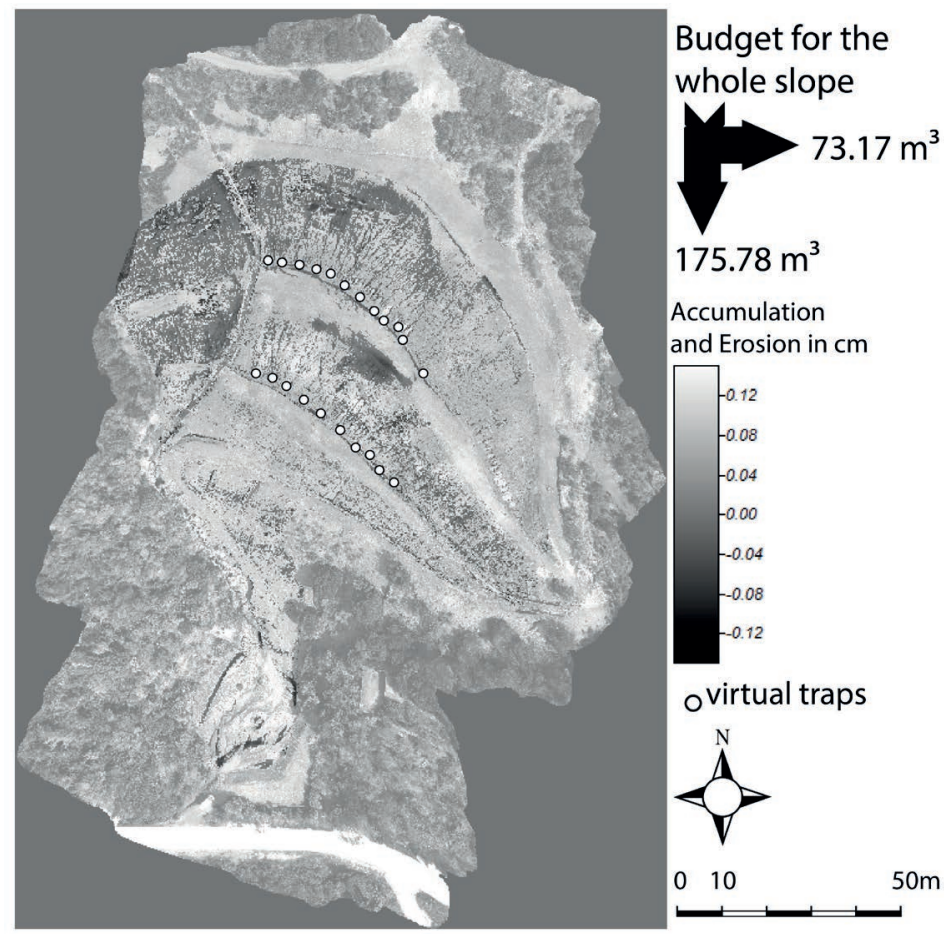

Fig. 3 Erosion and accumulation estimates for the Rio Marina study site from Sept. 2009 to April 2012. The arrows indicate the amount of material deposited on the slope and transported out of the area. "Virtual traps" are represented by circles. 
material was re-deposited in the study area. A total of $157.8 \mathrm{~m}^{3}$ of sediment was exported from the catchment. The average surface lowering for the entire slope was $3.9 \mathrm{~cm}$ for the three-year study period. The erosional pattern suggested the dominance of slope wash and rill erosion, which is in good agreement with the climatic conditions characterised by precipitation as rainfall, concentrated during winter. The presence of rill erosion confirmed the installation of stabilizing measures on the slopes, although it seems that debris flows cannot be stopped by these interventions.

\section{Relationship between catchment size and annual erosion rates}

The annual sediment delivery was related to the corresponding SCA at 19 (Lainbach valley) and 29 (Rio Marina) "virtual traps" at the foot of the study slopes. Both study areas showed a very strong agreement between SCA (hydrological catchment) and annual erosion rates, with higher rates at the Rio Marina study site (Fig. 4).

Several factors such as different climatic conditions with different precipitation regimes, different soil compositions and structures, slope angles or slope length could be the reason for the gap between the two study areas and they need further detailed analysis in the following years.

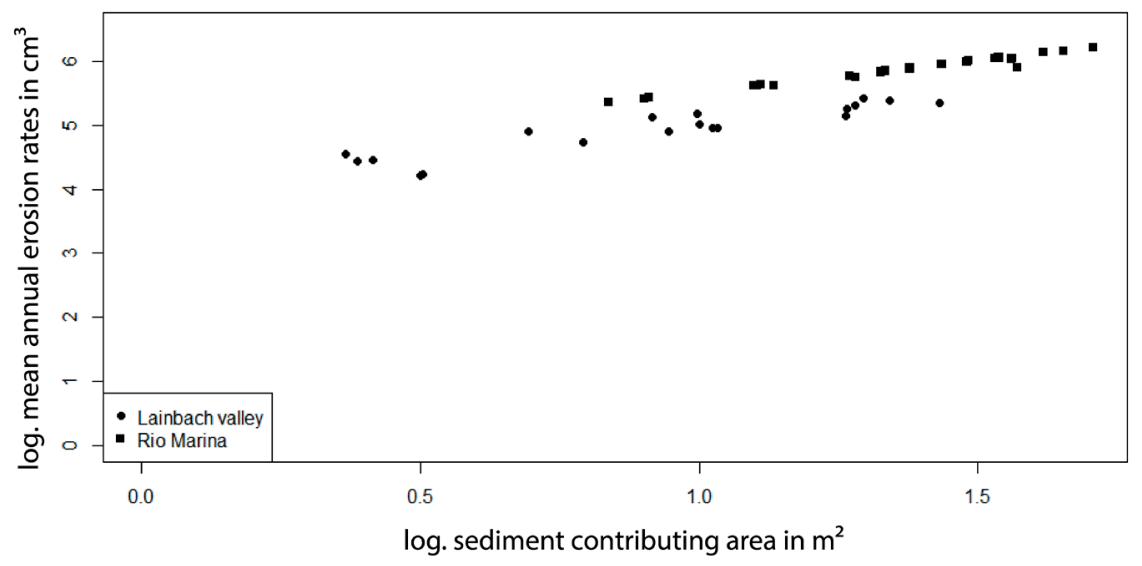

Fig. 4 Relationship between catchment size and mean annual erosion rates for the Lainbach valley and Rio Marina hill slopes.

\section{Comparison of TLS and UAV data using sfm}

The point densities of the TLS and sfm data varied greatly. Generally, the sfm point densities were distributed very homogeneously over the entire hill slope, whereas the TLS point cloud showed very high densities around the scan positions and in overlapping areas. Thus, TLS point clouds were distributed heterogeneously over the entire slope. Due to shadowing effects, the TLS data were compromised by less or even missing values in the gullied parts of the slopes. As the geometric angle is more favourable for using an UAV, these shadowing effects can be minimized by using DEMs from sfm (Fig. 5).

\section{CONCLUSION}

Both study areas show high geomorphic activity on the hill slopes. In the Lainbach valley catchment the eroded material is acting as possible debris flow material in the channel heads, whereas the eroded material at Rio Marina is polluted with heavy metals and is situated close to the Tyrrhenian Sea. Furthermore, the analysis showed erosion by rill erosion and small-scale debris flow, which confirms the installation of debris blockers at the slopes. The relevance for long-term monitoring of the hill slopes is therefore given at both sites. 

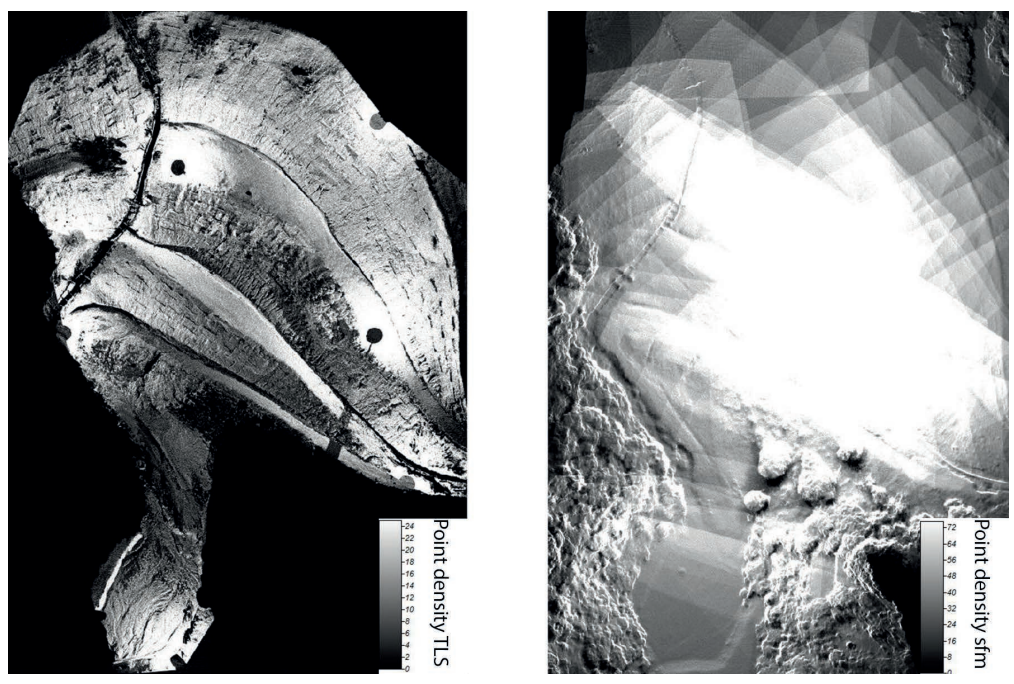

Fig. 5 Point densities for the Rio Marina study site. Note different colour scales for TLS (left) and sfm (right). Values indicate point count for each grid cell $(20 \times 20 \mathrm{~cm})$.

Different erosion patterns point out that there are different processes acting at the slopes. Mainly fluvial erosion at Rio Marina is in contrast to erosion dominated by slope failures and slides in combination with fluvial erosion in the Lainbach catchment. As both areas are characterized by different climatic conditions, monitoring with a higher temporal resolution could be helpful to distinguish between seasonal typical geomorphological processes, such as fluvial erosion, slope wash and even debris flows during heavy rain events and extensive erosion or small scale landslides following snow melt.

Furthermore the results show once again, that terrestrial LiDAR can be an appropriate tool to determine and analyse soil erosion on steep slopes. However TLS shows disadvantages for acquiring survey data even within a complex topography. This is why the use of an UAV and structure from motion algorithms will become a powerful tool for measuring erosion processes in complex landscapes.

Acknowledgements This work was supported by the German Science Foundation (DFG grant number: HA5740/3-1). Furthermore, the authors want to thank Adrian Collins for his useful review comments.

\section{REFERENCES}

Becht, M. (1995) Untersuchungen zur aktuellen Reliefentwicklung in alpinen Einzugsgebieten. Habilitation. University of Munich, Germany.

Brasington, J., Rumsby, B. T. \& McVey, R.A. (2000) Monitoring and modelling morphological change in a braided gravel-bed river using high resolution GPS-based survey. Earth Surf. Process. Landforms 25 (9), 973-990.

Bryan, R. B. (2000) Soil erodibility and processes of water erosion on hillslope. Geomorphology 32 (3-4), 385-415.

Clarke, M. L. \& H. M. Rendell (2006) Process-form relationships in southern Italian badlands: erosion rates and implications for landform evolution. Earth Surf. Process. and Landforms 31(1), 15-29.

Della Seta, M., et al. (2009) Space-time variability of denudation rates at the catchment and hillslope scales on the Tyrrhenian side of Central Italy. Geomorphology 107 (3-4), 161-177.

d'Oleire-Oltmanns, S., et al. (2012) Unmanned Aerial Vehicle (UAV) for monitoring soil erosion in Morocco. Remote Sensing 4 (12), 3390-3416.

Evans, M. \& Warburton, J. (2005) Sediment budget for an eroding peat-moorland catchment in northern England. Earth Surf. Process. Landforms 30(5), 557-577.

Felix, R. (1988) Die Niederschlagsverhältnisse. In: R. Felix, et al. (eds) Abfluß in Wildbächen. Untersuchungen im Einzugsgebiet des Lainbaches bei Benediktbeuern/Oberbayern, B 6. München: Geobuch-Verlag (B 6), 69-280.

Haas, F. (2008) Fluviale Hangprozesse in Alpinen Einzugsgebieten der Nördlichen Kalkalpen - Quantifizierung und Modellierungsansätze (Fluvial processes on alpine slopes of the northern Alps - Quantification and basic modelling approaches). Eichstätter Geographische Arbeiten Bd. 17, Munich, Vienna, Germany (in German).

Haas, F. \& Heckmann, T. (2007) Slope wash. In: A. A. Beylich \& J. Warburton (eds): SEDIFLUX Manual. Analysis of Sourceto-Sink Fluxes and Sediment Budgets in Changing High-Latitude and High-Altitude Cold Environments. Geological Survey of Norway Publication, 72-75. 
Haas, F., et al. (2011) Ground-based laserscanning - a new method for measuring fluvial erosion on steep slopes. In: GRACE, Remote Sensing and Ground-based Methods in Multi-scale Hydrology (ed. by M. M. Hafeez). IAHS Publ. 343, 163-168. IAHS Press, Wallingford, UK.

Haas, F., et al. (2012a) Runout analysis of a large rockfall in the Dolomites/Italian Alps using LIDAR derived particle sizes and shapes. Earth Surf. Process. Landforms 37(13), 1444-1455.

Haas, F., et al. (2012b) Quantification and modelling of debris flows in the proglacial area of the Gepatschferner, Austria, using ground-based LiDAR. In: Erosion and Sediment Yields in the Changing Environment (ed. by A.L. Collins, et al.). IAHS Publ. 356, 293-302. IAHS Press, Wallingford, UK.

Lindner, W. (2006) Digital Photogrammetry - A Practical Course. Springer, Berlin.

Milan, D. J., Heritage, G. L. \& Hetherington, D. (2007) Application of a 3D laser scanner in the assessment of erosion and deposition volumes and channel change in a proglacial river. Earth Surf. Process. Landforms 32 (11), 1657-1674.

Peter, K. D., et al. (2014) Soil erosion in gully catchments affected by land-levelling measures in the Souss Basin, Morocco, analysed by rainfall simulation and UAV remote sensing data. Catena $113,24-40$.

Priesmeier, K. (1988) Untersuchungsgebiet Lainbachtal. In: Abfluß in Wildbächen. Untersuchungen im Einzugsgebiet des Lainbaches bei Benediktbeuern/Oberbayern, B 6. (ed. by R. Felix, et al.). München: Geobuch-Verlag (B 6), 34-68.

Rieg, L., et al. (2014) Data infrastructure for multitemporal airborne LiDAR point cloud analysis - Examples from physical geography in high mountain environments. Computers, Environment and Urban Systems 45, 137-146.

Schürch, P., et al. (2011) Detection of surface change in complex topography using terrestrial laser scanning: application to the Illgraben debris-flow channel. Earth Surf. Process. Landforms 36 (14), 1847-1859.

Servida, D., Grieco, G. \& De Capitani, L. (2009) Geochemical hazard evaluation of sulphide-rich iron mines: The Rio Marina district. Journal of Geochemical Exploration 100, 75-89.

Sirvent, J., et al. (1997) Erosion rates in badland areas recorded by collectors, erosion pins and profilometer techniques (Ebro Basin, NE-Spain). Geomorphology 18 (2), 61-75.

Wirtz, S et al. (2012) Soil erosion on abandoned land in Andalusia: a comparison of interrill- and rill erosion rates. ISRN Soil Science 5, 1-16. 